\title{
"De QUe RIEM os PODERosos?" O RISO SOberano dA POESIA The poetry's sovereign laughter
}

\author{
Maria Heloísa Martins Dias*
}

\begin{abstract}
RESUMO
As relações tensivas entre o discurso autoritário do Poder e a resistência da fala poética sempre foi uma das preocupações dos escritores, em especial, dos que sabem fazer da linguagem literária, não uma arma de combate ou instrumento de engajamento, mas um espaço singular em que consciência lírica e sociedade dialogam na trama mais íntima do tecido poético. Eis o que um pensador como Adorno, por exemplo, mostrou muito bem em suas postulações sobre a arte e o poeta contemporâneo Affonso Romano de Sant 'Anna também exibe em seu poema "De que riem os poderosos?", contido em A catedral de colônia (1985). Nosso propósito é analisar como se dá esse "diálogo", por meio da reflexão sobre procedimentos estéticos presentes no texto do poeta brasileiro.
\end{abstract}

Palavras-chave: Affonso Romano de Sant’Anna; poesia; realidade sócio-política; transgressão.

\begin{abstract}
The tensive relationship between the authoritarian discourse of Power and the poetic speech of resistance has always been one of the writers' concern, especially of those who know how to make literary language neither a combat weapon nor an engagement instrument, but a singular space of lyric consciousness and society dialogue in the most intimate thread of the poetic tissue. This is what a thinker as Adorno, for instance, repeatedly showed from his postulate of art. Also, the contemporary poet Affonso Romano de Sant'Anna points it out in his poem "Do que riem os poderosos?" [What do powerful people laugh at?], in A catedral de Colonia (1985). Our paper aimed at analyzing how this "dialogue" happens, by investigating aesthetic procedures present in the Brazilian poet's text.
\end{abstract}

Keywords: Affonso Romano de Sant'Anna; poetry; social-politcal reality; transgression.

\section{RESUMEN}

Las relaciones en tensión entre el discurso autoritario del Poder y la resistencia del discurso poético siempre ha sido una de las preocupciones de los escritores, en especial, de los que saben hacer del lenguaje literario no un arma o instrumento de combate, sino un espacio singular en el que la conciencia lírica y la sociedad dialogan en la trama más íntima del tejido poético. El pensador Adorno, por ejemplo, ha señalado muy bien en sus postulados sobre el arte, como también el poeta contemporáneo Affonso Romano de San'Anna exibe en su poema De que riem os poderosos (1985). Nuestro objetivo es analizar como se construye tal "diálogo" por medio de procedimientos estéticos presentes en el texto del poeta brasileño.

Palabras-clave: Affonso Romano de San'Anna; poesía; realidad socio-política; transgresión.

\footnotetext{
Unesp/Ibilce/SP
} 
Affonso Romano de Sant'Anna e suas antenas literárias

O poeta, jornalista, crítico e professor universitário Affonso Romano de Sant' Anna esteve sempre antenado aos apelos culturais de seu tempo, confirmando o pensamento de Ezra Pound de que os artistas são as antenas de sua raça. ${ }^{1}$ Captação difícil, em que percepção sensível e consciência crítica entrelaçam seus fios para produzirem um discurso capaz de se afirmar ao mesmo tempo como arte e intervenção social.

A numerosa e diversificada produção literária de Sant'Anna, em especial a poética, vem confirmando a feliz conjunção daquilo que Adorno discutiu a propósito das relações entre lírica e sociedade em suas conferências. ${ }^{2}$ A tensão entre engajamento e realização estética por meio da linguagem poética rende resultados surpreendentes quando o que está em jogo não são soluções apressadas nem posições radicais, mas justamente formas de resistência de ambos os pólos para configurarem o diálogo entre ética e estética. É o que as poesias de Sant' Anna vêm oferecendo ao leitor.

Num momento em que se tornam agudas as questões em torno dos direitos humanos, cada vez mais ameaçados em sua essência, nada melhor do que afinarmos os ouvidos para a escuta de uma fala desafiadora, como a do poema "De que riem os poderosos?". Contido em A Catedral de Colônia, obra de 1985, o texto de Affonso Romano de Sant' Anna continua a despertar interesse, pois sua atualidade está na maneira hábil com que o poeta coloca em jogo duas formas distintas de poder: a do sistema político e a da linguagem poética que o desmascara. Evidentemente que não se trata de uma medição de forças, até porque a poesia não pretende se impor ou abrir caminho como numa luta de braços; os poderes de sua linguagem são bem outros, e tanto mais convincentes (sedutores?) quanto menos expõem os sentidos de que se arma.

Parece que a sedução exercida pela poesia está exatamente nessa singularidade com que ela oferece seu corpo simultaneamente aberto e impenetrável, a falar do real quanto mais dele se afasta. Algo que Adorno comentou, mas de outro modo. Ele não abordou essa natureza sedutora da lírica, porém apontou para a resistência encarnada na subjetividade dessa linguagem, que não significa desligamento ou alienação em relação à sociedade, como se costuma pensar. Ao contrário, o diálogo entre consciência e lirismo se revela não na transparência do discurso ou instantaneidade de seu enunciado, mas na forma como o sujeito lírico elabora a recusa dessa adesão, tensionando os vínculos entre arte e práxis.

\section{O poema "De que riem os poderosos?" em discussão}

Convém resgatarmos o poema de Sant' Anna para uma melhor reflexão sobre as questões apontadas acima.

De que riem os poderosos?
De que riem os poderosos?
tão gordos e melosos?
tão cientes e ociosos?
tão eternos e onerosos?

\footnotetext{
Em seu $A B C$ da Literatura. São Paulo: Cultrix, s.d.

2 Ver seu conhecido texto "Conferências sobre lírica e sociedade", contido em Notas de literatura (2003).
} 
Por que riem atrozes como olímpicos algozes, enfiando em nossos tímpanos seus alaridos e vozes?

De que ri o sinistro ministro com sua melosa angústia e gordurosa fala? Por que tão eufemístico exibe um riso político com seus números e levíticos, com recursos estatísticos fingindo gerar o gênesis, mas criando o apocalipse?

Riem místicos? ou terrenos riem, com seus mistérios gozosos, esses que fraudulentos se assentam flatulentos em seus misteres gasosos?

Riem sem dó? em dó maior? ou operísticos gargalham aos gritos como gralhas até ter dor no peito, até dar nó nas tripas em desrespeito? Ah, como esse riso de ogre empesteia de enxofre o desjejum do pobre.

Riem à tripa forra? riem só com a boca? riem sobre a magreza dos súditos famintos de realeza? riem na entrada e riem mais ? na sobremesa?

Mas se tanto riem juntos por que choram a sós, convertendo o eu dos outros num cordão de tristes nós? (SANT' ANNA, 1999, p. 21-22)

A inquietação do poeta, ou melhor, sua indignação revela-se já no título, por meio de uma pergunta que, longe de ser retórica, afia a consciência do sujeito na busca de possíveis respostas, fáceis de se encontrar, porém difíceis de se compreender. Mais do que os poderosos, o que incomoda o poeta é o riso absurdo que ostentam, eis o porquê do insistente questionamento do eu, existindo como um círculo ou como um "cordão de tristes nós" (último verso) amarrando o corpo da sociedade e o do próprio poema.

Sabemos, por meio de vários filósofos, desde os cínicos gregos, passando por Voltaire, Bergson, sendo teorizado por estudiosos como Bakthin e Propp, e desembocando no cancioneiro popular (a clássica "Máscara Negra", de Zé Keti, por exemplo), a importância que o riso desempenha enquanto manifestação humana, seja na realidade prática, seja na produção artística. Seu efeito catártico relacionado à correção dos costumes, segundo a máxima de Horácio, foi adquirindo diversos matizes e se transformando em poderosa arma a serviço da arte. Toda uma vasta literatura, em diversos momentos e espaços, já explorou o papel do riso e suas variantes, humor e comicidade, resultantes do escárnio, da sátira, da paródia, do grotesco, caricatura etc. Embora haja diferenças entre essas formas discursivas, não pretende-se focá-las aqui.

Para nossa reflexão interessa o que o riso, ou aquilo que Machado de Assis ilustrou tão bem com sua "pena da galhofa", contém por trás dessa aparência leve, nas dobras da enunciação discursiva. Ou seja, interessa-nos o gosto amargo do humor, jamais ingênuo ou superficial, posto que indiciador de valores a serem revistos, até mesmo revirados do avesso. Rimos, porque um deslocamento das expectativas habituais, ao promover desestabilizações, provoca o humor e, assim, somos surpreendidos.

Mas será esse o tipo de humor que move "os poderosos" no poema de Sant' Anna? E não haverá uma diferença entre aquele que ri e aquele que provoca o riso? Entre o riso espontâneo e o produzido ou manipulador?

Ao colocar o riso na boca dos poderosos, o eu lírico já está conferindo negatividade 
a esse gesto, isto é, rir estará associado a conotações indesejáveis, ao longo do poema, que obviamente não satisfazem "o desjejum do pobre" (último verso da $5^{\mathrm{a}}$ estrofe). Assim, o riso que emana da classe política dominante escancara-se tanto quanto a caracterização que esses sujeitos recebem: os "atrozes" e "algozes" são signos que não rimam apenas entre si, mas ecoam por todo o poema por meio de adjetivos que vão reiterando a imagem do Poder. "Gordos", "melosos", "cientes", "ociosos", "eternos", "onerosos", "olímpicos", "fraudulentos", "flatulentos" - atributos que contêm toda uma carga semântica marcada pela adiposidade, procedimento de linguagem que figurativiza o engordamento do sistema político.

A atuação arbitrária (e autoritária) do mando é comparada aos deuses do Olimpo, os quais, com proibições e castigos, conduziam o homem a labirintos e provações sem escapatória. Com a diferença nada pequena de que os "deuses" de nosso mundo são tão humanos quanto os seres que eles subjugam, o que torna mais perverso o seu domínio. As maldições ou falas sibilinas dos antigos deuses transformaram-se em "alaridos e vozes" ( $2^{\mathrm{a}}$ estrofe) que ferem nossos ouvidos, numa alusão aos discursos promissores, mas enganosos.

Os versos dão corpo à manobra retórica utilizada pelo Poder (não seria poder?), o que transparece na escolha de palavras proparoxítonas, características da fala rebuscada - "eufemístico", "político", "levíticos", "estatísticos" ( $3^{\mathrm{a}}$ estrofe) - apontando para uma prática discursiva modalizada pelo engodo. Os números e dados oferecidos pelo sistema instituído jamais correspondem à verdade e simulam uma visão progressista ou benéfica que oculta o caos, ou seja, ao invés do gênesis o apocalipse, como concluem os versos da $3^{\mathrm{a}}$ estrofe. A intertextualidade com a Bíblia transparece, por outro lado, na referência aos levíticos, um dos Livros bíblicos, atribuído a Levi.
Trata-se, afinal, de uma realidade permanentemente presente, cujo quadro conhecemos muito bem, ou parodiando Camões, "mudam-se os tempos, mudam-se as vontades", mas a condição humana não muda, permanece a artimanha como estratégia política.

A mística do Poder também é ironizada pelo poeta, na medida em que a aura enigmática que envolve os poderosos não resiste ao olhar crítico que a dessacraliza. É interessante notar como essa desmistificação se concretiza na linguagem, pois o gozo do mando se transforma em gases que se dissipam, graças ao jogo verbal entre "mistérios gozosos" e "misteres gasosos" (4a estrofe).

Voltemos a Adorno. É justamente esse poder da linguagem literária, cuja atuação está contida em sua corporalidade ou funcionalidade poética, que lhe permite atingir a realidade social; menos pelos sentidos ditos do que pela trama desse dizer pela enunciação.

Também podemos resgatar a antiga função do riso como purgação contra os males, aprendendo a eles resistir por força desse teatro de ridículos. Parece estarmos diante das peças alegóricas de Gil Vicente, com seu desfile de tipos grotescos exibindo vícios e pecados de toda ordem. Espécie de "ridendo, castigat mores" (Horácio), é assim que a $5^{\mathrm{a}}$ estrofe explora o cenário burlesco dos poderosos, comparando-os a uma opereta bufa.

Nesse momento do poema torna-se intenso o jogo com o significante, pois a sugestão musical potencializa a carnavalização do riso estúpido dos poderosos: "riem sem dó" / "dó maior" / "dor no peito" / "nó nas tripas" / "desrespeito". Há uma alternância lúdica entre som aberto e som fechado, o que nos leva a perceber esse discurso poético em diálogo com outro, dos tempos áureos do barroco brasileiro. Já em Gregório de Matos está presente a exploração das potencialidades verbais e efeitos lúdicos 
para a configuração da sátira sócio-política. ${ }^{3}$ Assim como nos sonetos de Gregório, no poema de Sant'Anna os sons se destacam enquanto realidade carnal, por meio de paronomásias ${ }^{4}$ e aliterações ${ }^{5}$, como em "gargalham", "gritos", "gralhas", "ogre". Também na poesia do poeta barroco as diferenças entre classes sociais, os desmandos e abusos do Poder, vícios e imoralidades são postas a nu pelo discurso crítico. $\mathrm{E}$ isto com a habilidade do trava-língua (note-se o $12^{\circ}$ verso do soneto de regório), cuja mensagem não tem nada de travado...

Como se vê, há um sincronismo nas produções poéticas, o que exige do leitor a percepção das intersecções criadas ao longo da cultura literária, e isso enriquece o jogo entre as temporalidades, tornando-as sempre abertas à visão crítica. Herança barroca, modernidade, vanguarda, esses fios vão se entretecendo para apagar as fronteiras rígidas do que chamaríamos tradição e, assim, desfazendo também o desejo desenfreado de ruptura. Octavio Paz que o diga ${ }^{6}$. Ora, essa projeção das constantes retomadas, ao longo da literatura, é sinal de que os problemas vividos pelos homens em sua luta social também se repetem, apenas mudando-se as configurações; no fundo, as diferenças, perversamente mantidas pelo poder, recobertas pela casca falsa da justiça existe desde que surgiu o mundo.

O curioso, no poema de Sant'Anna, é que a partir do desmascaramento do riso dos poderosos, o próprio eu lírico incorpora o riso em seu discurso, como acontece na $5^{\mathrm{a}}$ estrofe, graças ao investimento intenso nos efeitos lúdicos da camada verbal, conforme visto. É o momento em que a interrogação cede espaço à exclamação: "Ah, como esse riso de ogre / empesteia de enxofre / o desjejum do pobre.". A contraposição entre fracos e poderosos, típica de todos os tempos e eternamente insolúvel, patenteia-se nos versos citados, os quais denunciam a fome na mesa dos miseráveis, pois regada a enxofre. Notemos, nesse sentido, como permanece a alternância jocosa entre sons abertos e fechados (ogre/enxofre/pobre). Sem esquecer também que a imagem do ogre, desde tempos imemoriais, está associada à feiúra, ao grotesco, à deformação, enfim, àqueles seres fantásticos que não apenas alimentam o imaginário popular, mas os olhos dos ricos em sua visão dos pobres, como no poema.

A metáfora da comida, habilmente utilizada pelo poeta, aponta não apenas para a diferença de poder econômico entre ricos e pobres (aqueles "flatulentos" e "gordos", estes, marcados pela magreza, "famintos de realeza"), mas também para o fato de ser engolido pelos poderosos; estes, além de comerem bem, com direito à entrada e sobremesa, também comem a classe miserável, a deglutem.

Esse texto de Romano de Sant'Anna, como a maioria de suas poesias, apóia-se numa fala reiterativa, feita de eixos ou paradigmas

\footnotetext{
Lembremos, por exemplo, o paradigmático soneto "Contemplando nas cousas do mundo desde o seu retiro, lhe atira com o seu apage, como quem a nado escapou da tormenta" : Neste mundo é mais rico, o que mais rapa: / Quem mais limpo se faz, tem mais carepa: / Com sua língua ao nobre o vil decepa: / O Velhaco maior sempre tem capa. // Mostra o patife da nobreza o mapa: / Quem tem mão de agarrrar, ligeiro trepa: / Quem menos falar pode, mais increpa: / Quem dinheiro tiver, pode ser Papa. // A flor baixa se inculca por Tulipa; / Bengala hoje na mão, ontem garlopa: / Mais isento se mostra, o que mais chupa. // Para a tropa do trapo vazo a tripa, / E mais não digo, porque a Musa topa / Em apa, epa, ipa, opa, upa.". (2002).

4 Uma das figuras de linguagem que, desde os tempos da Retórica aristotélica vem sendo discutida. Consiste no emprego de vocábulos semelhantes na forma, mas opostos ou aparentados no sentido. No poema são paronomásias, por exemplo, "fraudulentos"/ "flatulentos", "algozes"/ "gozosos" etc.

5 Recurso sonoro, freqüente na linguagem poética, que consiste na repetição do mesmo som ou sílaba em diversas palavras no mesmo verso ou nos versos ao longo do poema.

6 Idéias defendidas em seu livro Los hijos del limo. Barcelona: Seix Barral, 1974.
} 
estruturadores do sentido. Em "De que riem os poderosos?", o poema repete o "riem", podendo ser essa uma forma de o poeta ir à forra, tal como fazem os que riem abusadamente.

O final do poema nos reserva um dado novo, não aguardado pela leitura, funcionando como um trunfo ou "forra" que o eu lírico parece lançar aos poderosos. Vejamos como.

Caracterizados, ao longo do poema, pela insensibilidade e crueldade, os poderosos estão destituídos de paixão, como se a emoção (e comoção) não fizesse parte de seu mundo. Pelo menos, de modo aparente. Assim, o riso seria sua única forma de manifestação anímica, a face debochada e perversa do Poder voltada aos súditos. Entretanto, um único verso, como se colocado en passant, despretensioso, desvela o que ficara oculto: "por que choram a sós", o antepenúltimo verso do poema. Choro escondido, como o são as verdadeiras intenções que movem todas as ações dos poderosos, significando que a fragilidade desses sujeitos não se mostra jamais. Por isso, a positividade desse gesto é relativa e o seu verdadeiro sentido (arrependimento? culpa? compaixão? fraqueza?) nunca saberemos. O que sabemos, aliás, desde o início do poema, é o que eles fazem com o eu dos outros: um "cordão de tristes nós", expressão em que o "nós" atua com significado duplo, podendo ser tanto a massa (todos nós) miserável e triste quanto os nós que a tornam amarrada à sua condição social.

\section{O poeta e suas antenas de longo alcance}

Eis o interesse desse texto que, apesar dos vinte e dois anos que dele nos separam, ainda contém verdades a serem apontadas pelo poeta. É que suas antenas continuam a captar os "mistérios gozosos", os quais não são nada agradáveis para a classe explorada, mas enchem de prazer os exploradores.

Em todos os tempos a função do artista tem sido a de lançar seu olhar crítico sobre a "máquina do mundo", aquela que Carlos Drummond de Andrade cantou em seu famoso poema. O eu lírico drummondiano lamenta ter suas pupilas gastas na inspeção do que a máquina lhe oferece e, embora sua consciência peregrine pelo espaço à procura de soluções para o enigma do universo, ele recusa a oferta, respeitosamente. Já em Affonso Romano de Sant'Anna, ao contrário, a reação do sujeito lírico diante do funcionamento do mundo (ou da maquinaria humana) não se revela respeitosa ou humilde. Nem poderia, porque os danos sobre os homens (os mais fracos) é tal que não há como fazer frente ao desrespeito dos que riem sem dó, a não ser por meio de uma linguagem também marcada pelo riso.

Não se trata de vingança, pois não cabe tentar corrigir a violência por meio de outra violência. Como disse antes, os poderes da arte são distintos do Poder, marcado por um autoritarismo que em nada corresponde à liberdade da criação.

Para quem pensa que é preciso fazer justiça com as próprias mãos, então a melhor forma de a poesia responder a esse direito é utilizar as armas que o seu espaço interno de operação oferece à linguagem como intervenção criadora. Dentre essas armas está, sem dúvida, a ousadia do poeta em desmontar a aparelhagem dos sistemas dominantes em favor de realidades menos indesejáveis. Nesse caso, poderíamos também terminar, assim como Affonso em seu poema, com uma pergunta:

Por que não desatarmos os nós que nos prendem sem precisarmos desatar a nós mesmos? 


\section{REFERÊNCIAS}

ADORNO, T. Conferência sobre lírica e sociedade. In: Notas de literatura I. São Paulo: Duas Cidades/Ed. 34, 2003.

MATOS, G. de. Poemas satíricos. São Paulo: Martin Claret, 2002.

PAZ, O. Los hijos del limo. Barcelona: Seix Barral, 1974.
POUND, E. Abc da literatura. São Paulo: Cultrix, s.d.

SANT'ANNA, A. R. de. A Catedral de colônia. Rio de Janeiro: Rocco, 1985.

Intervalo amoroso \& outros poemas escolhidos. Porto Alegre: L\&PM, 1999.

Texto recebido em 15 fev. 2008. Texto aprovado em 21 mai. 2008. 